\title{
Antipsychotic drugs in epilepsy
}

\author{
Natalia Górska, Jakub Słupski, Wiesław J. Cubała \\ Department of Psychiatry, Medical University of Gdansk, Gdansk, Poland
}

\begin{abstract}
The prevalence of various psychiatric disorders in people with epilepsy is high, with psychoses affecting 2-9\% of patients. Antipsychotic drugs have been identified as increasing the risk of epileptic seizures. For first-generation antipsychotics such a risk appears to be relatively low, with the exception of chlorpromazine. Among second-generation antipsychotics, clozapine use carries the highest risk of seizure induction, while risperidone, quetiapine, amisulpride, and aripiprazole seem to pose a significantly lower risk. The incidence of an increased number of seizures is linked to the elevated blood plasma level effect of antipsychotics. To diminish the risk of seizures, it is important to start with a small dose of antipsychotic drug, to titrate slowly, to monitor serum levels of prescribed drugs, and to keep the drug at the minimal effective dose.
\end{abstract}

Key words: antipsychotic drugs, epilepsy, psychosis

(Neurol Neurochir Pol 2019; 53 (6): 408-412)

\section{Introduction}

Psychiatric comorbidity is common in people with epilepsy, with 11-62\% prevalence of mood disorders, and psychoses affecting 2-9\% of patients. Furthermore, psychotic disorders for which antipsychotic drugs may be prescribed are more common among people with epilepsy than in the general population $[1,2,3,4,5]$.

Psychoses in people with epilepsy are categorised as peri-ictal or interictal psychoses. Peri-ictal psychoses can be divided into pre-ictal, ictal, and postictal. Interictal psychoses occur without a time relation with epileptic seizures [6]. It is worth noting that interictal psychoses most commonly occur in temporal epilepsy [7].

Almost all first- and second-generation antipsychotics are implicated in increasing the risk of epileptic seizures [8, 9]. Electroencephalography (EEG) can be used to monitor patients suspected of seizures. EEG alterations without clinical repercussions are found in about $7 \%$ of antipsychotic drug users without a diagnosis of epilepsy, and $0.5-1.2 \%$ of them exhibited seizures [5].

\section{Mechanism of psychosis in epilepsy}

Dopaminergic activity is proven to have an impact on the development of psychosis, with dopamine antagonism being pro-convulsive and antipsychotic. The clinical efficacy of antipsychotic drugs is heavily correlated with their ability to block subcortical dopamine D2 receptors [10]. Focusing on epileptogenesis, there is recent evidence from both animal and human studies supporting the role of D1 and D2 receptor signalling in limbic epilepsy. These studies point out that increased D1 receptor and decreased D2 receptor function might be involved in limbic epilepsy [11]. Bozzi and Borrelli have proposed that altered D1R and D2R signalling might contribute to epileptogenesis through the activation of neuronal cell death cascades, activated by the protein kinase A (PKA)/ /extracellular-regulated kinase (ERK) and mammalian target of rapamycin (mTOR) pathways [11].

Antiepileptic drugs have been reported to have an impact on increasing the risk of psychosis. However the risk is small, with reported prevalences of $2.5 \%$ for vigabatrin, $1.9-2.3 \%$ for zonisamide, $0.8 \%$ for topiramate, $0.3-0.7 \%$ for levetiracetam, and $0.5 \%$ for gabapentin [12].

\section{Antipsychotic drugs}

First-generation antipsychotics

Chlorpromazine is thought to be particularly associated with a higher risk of provoking epileptic seizures. In a more than four-year long observational study by Logothetis et al. [13], all nonepileptic patients treated with first-generation 
antipsychotic drugs were studied for spontaneous seizures. $1.2 \%$ of 859 patients treated with phenothiazines experienced seizures, while no seizures occurred in the 669 patients with treatment other than phenothiazines. Two factors increasing the probability for seizures were found: the application of high dosages, and the time span around the initiation or escalation of the phenothiazine dose. Seizures occurred in $9 \%$ of the patients treated with high doses of first-generation antipsychotic drugs $(1,000 \mathrm{mg} /$ day chlorpromazine equivalent), in $0.7 \%$ of the patients with moderate doses, and in $0.3 \%$ of the patients with low doses (200 mg/day chlorpromazine equivalent) [13].

The piperazine phenothiazines (acetophenazine, fluphenazine, perphenazine, prochlorperazine and trifluoperazine) exhibit epileptogenic activity of less potential, while the lowest epileptogenic effect among first-generation antipsychotic drugs has been observed with piperidine phenothiazines (e.g. thioridazine) and butyrophenones (e.g. haloperidol) $[8,14,15]$. Haloperidol has been proven not to decrease the epileptic threshold significantly, which is why it should be considered in the treatment of acute and chronic psychoses in people with epilepsy [8, $16,17,18]$. The high affinity with D2 dopaminergic receptors presented by haloperidol results in antipsychotic action at low doses, which reduces the risk of seizures [14]. The only antipsychotic drug presenting no reported seizure risk, and in addition having a possible seizure-protective capability, is melperone (a drug not currently available in Poland). This is a sedative butyrophenone of low potency [19].

\section{Second-generation antipsychotics}

Clinical registries reveal a seizure incidence of $0.3-0.9 \%$ for most second-generation antipsychotic drugs [14]. Risperidone, olanzapine and quetiapine appear to be safe compared to chlorpromazine in terms of seizures. The anticonvulsive effect of dopamine is broadly known. Drugs selective for mesolimbic dopamine receptors, e.g. clozapine, olanzapine and quetiapine, exhibit more intense proconvulsive effects than drugs with low affinity to $\mathrm{D} 2$ receptor such as risperidone [20,21]. Olanzapine and quetiapine have demonstrated seizure rates of $0.9 \%$ while risperidone has presented even lower rates $(\sim 0.3 \%)[22,23]$.

Another study of 15 patients did not show an increase in seizures, even in cases of risperidone overdose [24]. In different studies, olanzapine has exhibited occurrence of seizures in $0.24 \%$ [25], while in patients treated with quetiapine and a placebo no increase in seizure incidence was observed $(0.4 \%$ and $0.5 \%$ respectively) [26]. The use of aripiprazole (the partial agonist of dopamine receptor) has been associated with a seizure rate of $0.1 \%$ in patients treated in short-term, premarketing placebo-controlled trials $[8,27]$. In a study by Bloechliger et al. [28], aripiprazole and risperidone were among the second-generation antipsychotic drugs with the lowest seizure incidence.

However, according to Lertxundi et al. [29], some second-generation antipsychotic drugs (especially clozapine) may carry a greater epileptogenic risk than first-generation antipsychotics. Olanzapine and quetiapine, both presenting significant chemical similarity to clozapine, may carry a higher risk than previously thought. It is worth noing that other research has not confirmed a greater epileptogenic risk in the case of olanzapine and quetiapine compared to first-generation antipsychotic drugs.

Clozapine was associated with a higher seizure incidence than other second-generation antipsychotic drugs $-3.5 \%$ - in premarketing studies $[16,30]$. Its use in epilepsy is restricted to cases of severe psychosis which are refractory to other antipsychotic drugs. Very rapid titration and the use of high doses of clozapine are the triggers of occurrence of seizures which increase by $0.7 \%$ for each $100 \mathrm{mg}$ of the drug. Up to $300 \mathrm{mg} /$ day, the risk of seizures is comparable to other antipsychotic drugs. Between 600 and $900 \mathrm{mg} /$ day, this risk reaches 5\% [31]. Electroencephalogram abnormalities have been reported in $1 \%$ for doses of less than $300 \mathrm{mg}$ of clozapine a day, in $2.7 \%$ for $300-600 \mathrm{mg}$, and in $4.4 \%$ of patients for clozapine doses of $600-900 \mathrm{mg}$ a day [32]. A postmarketing study of $>5,000$ patients with clozapine indicated a lower incidence rate $(1.3 \%)$, without dose dependency [33].

On the other hand, the positive effect of antipsychotic drugs in epilepsy patients has also been described. Antipsychotic drugs may induce beneficial effects on the mental state of people with epilepsy [17]. A decreasing effect on seizure frequency has been found. For example, the use of aripiprazole, melperone and thioridazine at therapeutic doses has been reported to reduce the occurrence of seizures in patients with epilepsy $[18,19,34,50]$.

\section{Seizures and antipsychotics}

According to Ojemann [36] and Gross [37] (based on respectively 13 and seven case reports), seizure frequency did not increase while treating epilepsy patients with comparatively low doses of antipsychotic drugs. After one month of treatment, the seizure outcome was markedly better in the antipsychotic drug user group than in the control group; only two patients with antipsychotic drugs (1.3\%) exhibited an increase in seizure frequency compared to the baseline, while 13 controls (4\%) experienced an increase. Patients who are already on an antiepileptic drug can be safely treated with a variety of antipsychotic drugs, according to a larger study with a matched control group conducted by Okazaki [34]. The seizure outcome between first- and second-generation antipsychotic drugs, or between mono- and polypharmacy, was not significantly different. However, clozapine was not included in this study. The seizure outcome in people with epilepsy improved throughout the one-year follow-up period after the administration of antipsychotic drugs for psychiatric conditions [34].

\section{Using antipsychotic drugs in clinical practice (Tab. 1)}

When starting any drug therapy, some general risk factors for seizures have to be considered, including pharmacodynamic 
Table 1. Antipsychotic drugs in epilepsy — range of clinical features

\begin{tabular}{|c|c|c|c|c|c|c|c|}
\hline Group & Drug name & $\begin{array}{c}\text { CYP } \\
\text { metabolism }\end{array}$ & $\mathrm{T} 1 / 2$ & Route & $\begin{array}{c}\text { Most common side } \\
\text { effects }\end{array}$ & $\begin{array}{l}\text { Interactions with } \\
\text { antipsychotic drugs }\end{array}$ & $\begin{array}{l}\text { Seizure } \\
\text { risk }\end{array}$ \\
\hline \multicolumn{8}{|l|}{$\begin{array}{l}\text { First-generation } \\
\text { antipsychotic } \\
\text { drugs }\end{array}$} \\
\hline \multirow[t]{3}{*}{$\begin{array}{l}\text { Phenothiazines } \\
{[12,13,14]}\end{array}$} & Chlorpromazine & $\begin{array}{l}\text { CYP2D6 } \\
\text { mostly, CY- } \\
\text { P1A2, CYP3A4 }\end{array}$ & $30 \mathrm{~h}$ & Oral/i.m. & $\begin{array}{l}\text { Akathysia, dysthonia, } \\
\text { dyskineses, leukopenia, } \\
\text { hyperprolactinemia, rash }\end{array}$ & $\begin{array}{l}\text { Carbamazepine } \\
\text { - potenatial agranu- } \\
\text { locytosis }\end{array}$ & $1.2 \%[13]$ \\
\hline & Promazine & No data & $20-40 \mathrm{~h}$ & Oral & $\begin{array}{l}\text { Orthostatic hypotonia, } \\
\text { arrythmia }\end{array}$ & $\begin{array}{l}\text { Less effective, } \\
\text { carbamazepine - po- } \\
\text { tential neurotoxicity }\end{array}$ & \\
\hline & $\begin{array}{l}\text { Levomeproma- } \\
\text { zine }\end{array}$ & $\begin{array}{l}\text { CYP2D6, } \\
\text { CYP3A4 }\end{array}$ & $15-30 \mathrm{~h}$ & Oral/i.m. & $\begin{array}{l}\text { Orthostatic hypotonia, } \\
\text { disorientation, visual } \\
\text { hallucinations, blurred } \\
\text { speech, elevated intrac- } \\
\text { ranial pressure, seizures }\end{array}$ & Non significant & \\
\hline $\begin{array}{l}\text { Butyropheno- } \\
\text { nes }\end{array}$ & Haloperidol [38] & $\begin{array}{l}\text { CYP3A4, } \\
\text { CYP2D6 }\end{array}$ & $12-37 \mathrm{~h}$ & Oral/i.m. & $\begin{array}{l}\text { Parkinson's syndrome, } \\
\text { akathysia, late dyskineses, } \\
\text { dysthonia, neuroleptic } \\
\text { malignant syndrome }\end{array}$ & $\begin{array}{l}\text { Carbamazepine - drug } \\
\text { serum level decrease }\end{array}$ & $\begin{array}{l}\text { Low [8, } \\
15]\end{array}$ \\
\hline \multirow{6}{*}{$\begin{array}{l}\text { Second- } \\
\text {-generation } \\
\text { antipsychotic } \\
\text { drugs }\end{array}$} & Olanzapine [39] & $\begin{array}{l}\text { CYP1A2, } \\
\text { CYP2D6 }\end{array}$ & $34 \mathrm{~h}$ & Oral/i.m. & $\begin{array}{l}\text { Sedation, weight gain, } \\
\text { hyperprolactinemia }\end{array}$ & \multirow{4}{*}{$\begin{array}{l}\text { Phenobarbital, phe- } \\
\text { nytoin, primidone, } \\
\text { carbamazepine } \\
\text { - increased drug } \\
\text { metabolism (with } \\
\text { the exception of } \\
\text { phenytoin, which } \\
\text { inhibits risperidone } \\
\text { clearance) }\end{array}$} & $\begin{array}{l}0.9 \% \\
{[22,23]}\end{array}$ \\
\hline & Quetiapine [40] & CYP3A4 & $7 \mathrm{~h}$ & Oral/i.m. & $\begin{array}{l}\text { Sedation, dizziness, hea- } \\
\text { dache, hyperlipidemia }\end{array}$ & & \\
\hline & Risperidone [41] & CYP2D6 & $\begin{array}{l}3 \mathrm{~h} \text { (active } \\
\text { metaboli- } \\
\text { te }-24 \mathrm{~h} \text { ) }\end{array}$ & Oral/i.m. & $\begin{array}{l}\text { Parkinson's syndrome, } \\
\text { headache, insomnia }\end{array}$ & & $\begin{array}{l}0.3 \% \\
{[22,23]}\end{array}$ \\
\hline & Aripiprazole [42] & $\begin{array}{l}\text { CYP3A4, } \\
\text { CYP2D6 }\end{array}$ & $75 \mathrm{~h}$ & Oral/i.m. & $\begin{array}{l}\text { Anxiety, insomnia, } \\
\text { extrapyramidal symp- } \\
\text { toms, akathysia, tremor, } \\
\text { dizziness }\end{array}$ & & $\begin{array}{l}0.1 \% \\
{[8,27]}\end{array}$ \\
\hline & $\begin{array}{l}\text { Clozapine } \\
{[43,44]}\end{array}$ & $\begin{array}{l}\text { CYP1A2, } \\
\text { CYP3A4 }\end{array}$ & $12 \mathrm{~h}$ & Oral & $\begin{array}{l}\text { Tachycardia, sedation, } \\
\text { dizziness, constipation, } \\
\text { hypersalivation }\end{array}$ & $\begin{array}{l}\text { Carbamazepine } \\
\text { - bone marrow sup- } \\
\text { pression, increased } \\
\text { drug metabolism }\end{array}$ & $\begin{array}{l}3.5-5 \% \\
{[16,30,} \\
31]\end{array}$ \\
\hline & Amisulpride [45] & Not involved & $12 \mathrm{~h}$ & Oral & $\begin{array}{l}\text { Parkinson's syndrome, } \\
\text { dysthonia, sleep disor- } \\
\text { ders, hyperprolactinemia }\end{array}$ & Not significant & $\begin{array}{l}0.24 \% \\
{[28]}\end{array}$ \\
\hline
\end{tabular}

and pharmacokinetic interactions, drug selection, drug dosage, and patient-related factors. The expected therapeutic drug effects may be changed by pharmacokinetic interactions between antipsychotic drugs and antiepileptic drugs that arise from the common metabolism pathway through isoenzymes of cytochrome P-450 [5, 14].

While choosing antipsychotic drugs, clinicians must consider not only lowering the seizure threshold, but also other side-effects such as weight gain and sedation, especially in concurrent use with antiepileptic drugs (e.g. valproate and vigabatrine, carbamazepine or barbiturates). Both first- and second-generation antipsychotic drugs cause an extrapyramidal syndrome, especially so with first-generation drugs. However, compared to first-generation antipsychotic drugs, second-generation antipsychotic drugs cause more severe side effects in term of weight gain and metabolic syndrome [38].
Enzyme-inducing antiepileptic drugs such as phenobarbital, phenytoin, primidone, and carbamazepine, may increase the clearance of psychotropic drugs metabolised in the liver, including first-generation antipsychotic drugs (chlorpromazine, fluphenazine and haloperidol) and second-generation antipsychotic drugs (clozapine, olanzapine, quetiapine, aripiprazole, and risperidone, with the exception of phenytoin, which inhibits risperidone clearance).

The addition of any of these inducers may be associated with a decrease in serum concentration of antipsychotic drugs that may evoke a lack of efficacy. On the other hand, the discontinuation of enzyme inducers may be bound up with an increased serum antipsychotic drug concentration and result in adverse drug reactions. Some first-and second-generation antipsychotic drugs (respectively haloperidol, loxapine, and risperidone, quetiapine) may inhibit the clearance of some enzyme-inducing antiepileptic drugs, in particular phenytoin 
and carbamazepine. The pharmacokinetic drug interactions assigned to valproate, eslicarbazepine, felbamate, oxcarbazepine, rufinamide and topiramate are generally non-clinically relevant in most patients taking antipsychotic drugs, but it is possible that in some unusual patients these agents may have clinical relevance. It has been reported that valproic acid reduces the clearance of antipsychotic drugs $[4,39,34]$, inducing the metabolism of clozapine [40] and olanzapine [41]. Valproates seem to have no impact on quetiapine metabolism [42].

In an animal study by Syrek et al., pharmacokinetic interaction between promazine and carbamazepine led to an initial increase of promazine concentration, followed by a significant decrease over the next few hours [43].

Carbamazepine should be avoided if possible as concurrent medication with clozapine due to the risk of suppression of the bone marrow induced by the combination of these drugs, particularly the risk of agranulocytosis induced by clozapine [26]. It is important to emphasise that clozapine itself can provoke haematological disorders, and that haematological monitoring is needed [31]. Special consideration should be given to amisulpride because it does not cause pharmacokinetic interactions as it has renal elimination; other advantages of this agent are: its very low risk of triggering seizures; no haematotoxic potential; and minimal hepatotoxic potential [28].

\section{Conclusion}

Antipsychotic drugs can be used both in inpatient and outpatient populations, as well as in chronic and acute treatment. Among the first-generation antipsychotic drugs, the greatest risk of provoking epileptic seizures is assigned to chlorpromazine, while piperazine and piperidine phenothiazines, and butyrophenones, have been reported to be associated with a lower risk of seizure induction than other first-generation antipsychotic drugs.

Among second-generation antipsychotic drugs, clozapine use carries the highest risk of reducing seizure threshold, while risperidone, quetiapine, amisulpride, and aripiprazole seems to confer a relatively low such risk. The seizure-risk increase is linked to the high blood plasma levels of antipsychotics (e.g. due to interactions or in cases of overdose).

To diminish the risk of seizures, it is important to start with a small dose of antipsychotic drugs, to titrate slowly, to monitor serum levels of prescribed drugs, and to keep antipsychotic drugs at the minimal effective dose.

Ethical approval: not necessary for preparation of this article. Conflict of interest: Dr Cubała has received research support from Actavis, Alkermes, Allergan, Auspex, Biogen, Bristol-Myers Squibb, Cephalon, Eli Lilly, Ferrier, Forest Laboratories, Gedeon Richter, GW Pharmaceuticals, Janssen, KCR, Lundbeck, Orion, Otsuka, Sanofi, and Servier; he has served on speaker bureaus for Adamed, Angelini, AstraZeneca, Bristol-Myers Squibb, Celon, GlaxoSmithKline, Janssen, Krka, Lekam, Lundbeck, Novartis,
Orion, Pfizer, Polfa Tarchomin, Sanofi, Servier, and Zentiva; and he has served as a consultant for GW Pharmaceuticals, Janssen, KCR, Quintiles, and Roche.

Dr Górska has received research support from Actavis, Eli Lilly, Minerva Neurosciences, and Sunovion Pharmaceuticals. Dr Słupski has received research support from Actavis, Eli Lilly, Minerva Neurosciences, and Sunovion Pharmaceuticals.

\section{References:}

1. Adelöw C, Andersson T, Ahlbom A, et al. Hospitalization for psychiatric disorders before and after onset of unprovoked seizures/ epilepsy. Neurology. 2012; 78(6): 396-401, doi: 10.1212/ WNL.0b013e318245f461, indexed in Pubmed: 22282649.

2. Vuilleumier P, Jallon P. [Epilepsy and psychiatric disorders: epidemiological data]. Rev Neurol (Paris). 1998; 154(4): 305-317, indexed in Pubmed: 9773058.

3. Gaitatzis A, Trimble MR, Sander JW. The psychiatric comorbidity of epilepsy. Acta Neurol Scand. 2004; 110(4): 207-220, doi: 10.1111/j.1600-0404.2004.00324.x, indexed in Pubmed: 15355484.

4. Wiglusz MS, Cubała WJ, Gałuszko-Węgielnik M, et al. Mood disorders in epilepsy - diagnostic and methodological considerations. Psychiatr Danub. 2012; 24 Suppl 1: S44-S50, indexed in Pubmed: 22945186.

5. de To, Trimble M, Hesdorffer DC, et al. Pharmacotherapy in patients with epilepsy and psychosis. Epilepsy Behav. 2018; 88: 54-60.

6. González Mingot C, Gil Villar MP, Calvo Medel D, et al. Epileptic periictal psychosis, a reversible cause of psychosis. Neurologia. 2013; 28(2): 81-87, doi: 10.1016/j.nrl.2012.03.005, indexed in Pubmed: 22703628.

7. Kanemoto $\mathrm{K}$, Tadokoro $\mathrm{Y}$, Oshima T, et al. Psychotic illness in patients with epilepsy. Ther Adv Neurol Disord. 2012; 5(6): 321-334, doi: 10.1177/1756285612454180, indexed in Pubmed: 23139703.

8. Hedges D, Jeppson K, Whitehead P. Antipsychotic medication and seizures: a review. Drugs Today (Barc). 2003; 39(7): 551-557, indexed in Pubmed: 12973403.

9. Dias Alves M, Micoulaud-Franchi JA, Simon N, et al. Electroencephalogram Modifications Associated With Atypical Strict Antipsychotic Monotherapies. J Clin Psychopharmacol. 2018; 38(6): 555-562, doi: 10.1097/JCP.0000000000000953, indexed in Pubmed: 30247179.

10. Kesby JP, Eyles DW, McGrath JJ, et al. Dopamine, psychosis and schizophrenia: the widening gap between basic and clinical neuroscience. Transl Psychiatry. 2018; 8(1): 30, doi: 10.1038/s41398-0170071-9, indexed in Pubmed: 29382821.

11. Bozzi Y, Borrelli E. The role of dopamine signaling in epileptogenesis. Front Cell Neurosci. 2013; 7: 157, doi: 10.3389/fncel.2013.00157, indexed in Pubmed: 24062645.

12. Maguire M, Singh J, Marson A. Epilepsy and psychosis: a practical approach. Pract Neurol. 2018; 18(2): 106-114, doi: 10.1136/practneurol-2017-001775, indexed in Pubmed: 29273616.

13. Logothetis J. Spontaneous epileptic seizures and electroencephalographic changes in the course of phenothiazine therapy. Neurology. 1967; 17(9): 869-877, doi: 10.1212/wnl.17.9.869, indexed in Pubmed: 6069087.

14. Koch-Stoecker S. Antipsychotic drugs and epilepsy: indications and treatment guidelines. Epilepsia. 2002; 43(s2): 19-24, doi: 10.1046/j.1528-1157.2002.043s2019.x, indexed in Pubmed: 11903478. 
15. Witten DM, Hirsch FD, Hartman GW. Acute reactions to urographic contrast medium: incidence, clinical characteristics and relationship to history of hypersensitivity states. Am J Roentgenol Radium Ther Nucl Med. 1973; 119(4): 832-840, doi: 10.2214/ajr.119.4.832, indexed in Pubmed: 4765627.

16. Kumlien E, Lundberg PO. Seizure risk associated with neuroactive drugs: data from the WHO adverse drug reactions database. Seizure. 2010; 19(2): 69-73, doi: 10.1016/j.seizure.2009.11.005, indexed in Pubmed: 20036167.

17. Pisani F, Oteri G, Costa C, et al. Effects of psychotropic drugs on seizure threshold. Drug Saf. 2002; 25(2): 91-110, doi: 10.2165/00002018200225020-00004, indexed in Pubmed: 11888352.

18. Citraro R, Leo A, Aiello R, et al. Comparative analysis of the treatment of chronic antipsychotic drugs on epileptic susceptibility in genetically epilepsy-prone rats. Neurotherapeutics. 2015; 12(1): 250-262, doi: 10.1007/s13311-014-0318-6, indexed in Pubmed: 25404052.

19. Benkert 0 , Hippius H. Intoxikationen. Kompendium der Psychiatrischen Pharmakotherapie. 2000: 389-400, doi: 10.1007/978-3-662 12174-0_13.

20. Starr MS. The role of dopamine in epilepsy. Synapse. 1996; 22(2): 159-194, doi: 10.1002/(SICI)1098-2396(199602)22:2<159::AIDSYN8>3.0.C0;2-C, indexed in Pubmed: 8787131.

21. Minabe $\mathrm{Y}$, Watanabe $\mathrm{K}$, Nishimura $\mathrm{T}$, et al. Acute and chronic administration of clozapine produces greater proconvulsant actions than haloperidol on focal hippocampal seizures in freely moving rats. Synapse. 1998; 29(3): 272-278, doi: 10.1002/(SICI)10982396(199807)29:3<272::AID-SYN10>3.0.C0;2-V, indexed in Pubmed: 9635898.

22. Alldredge BK. Seizure risk associated with psychotropic drugs: clinical and pharmacokinetic considerations. Neurology. 1999; 53(5 Suppl 2): S68-S75, indexed in Pubmed: 10496236.

23. Alper K, Schwartz KA, Kolts RL, et al. Seizure incidence in psychopharmacological clinical trials: an analysis of Food and Drug Administration (FDA) summary basis of approval reports. Biol Psychiatry. 2007; 62(4): 345-354, doi: 10.1016/j.biopsych.2006.09.023, indexed in Pubmed: 17223086.

24. Acri AA, Henretig FM. Effects of risperidone in overdose. Am J Emerg Med. 1998; 16(5): 498-501, doi: 10.1016/s0735-6757(98)90001-8, indexed in Pubmed: 9725965.

25. Long PW. Olanzapine drug monograph (from file Lilly) and Zotepine drug monograph. Internet Mental Health; 1996.

26. Torta R, Keller R. Behavioral, psychotic, and anxiety disorders in epilepsy: etiology, clinical features, and therapeutic implications. Epilepsia. 1999; 40 Suppl 10: S2-20, doi: 10.1111/j.1528-1157.1999. tb00883.x, indexed in Pubmed: 10609602.

27. Physician's Desk Reference, Prescribing information for aripiprazole. Montvale: Medical Economics; 2006.

28. Bloechliger M, Rüegg S, Jick SS, et al. Antipsychotic drug use and the risk of seizures: follow-up study with a nested case-control analysis. CNS Drugs. 2015; 29(7): 591-603, doi: 10.1007/s40263-0150262-y, indexed in Pubmed: 26242478.
29. Lertxundi U, Hernandez R, Medrano J, et al. Antipsychotics and seizures: higher risk with atypicals? Seizure. 2013; 22(2): 141-143, doi: 10.1016/j.seizure.2012.10.009, indexed in Pubmed: 23146619.

30. Wilson WH, Claussen AM. Seizures associated with clozapine treatment in a state hospital. J Clin Psychiatry. 1994; 55(5): 184-188, indexed in Pubmed: 8071267.

31. Owens MJ, Risch SC. Atypical antipsychotic. In: Schatzberg AF, Nemeroff $\mathrm{CB}$, eds. Textbook of psychopharmachology. Washington (DC): Am Psychiatric Press; 1995: 263-280.

32. Devinsky 0, Honigfeld G, Patin J. Clozapine-related seizures. Neurology. 1991; 41(3): 369-371, doi: 10.1212/wnl.41.3.369, indexed in Pubmed: 2006003.

33. Pacia SV, Devinsky 0. Clozapine-related seizures: experience with 5,629 patients. Neurology. 1994; 44(12): 2247-2249, doi: 10.1212/ wnl.44.12.2247, indexed in Pubmed: 7991106.

34. Okazaki M, Adachi N, Akanuma N, et al. Do antipsychotic drugs increase seizure frequency in epilepsy patients? Eur Neuropsychopharmacol. 2014; 24(11): 1738-1744, doi: 10.1016/j.euroneuro.2014.09.012, indexed in Pubmed: 25453222.

35. PAUIG PM, DELUCA MA, OSTERHELD RG. Thioridazine hydrochloride in the treatment of behavior disorders in epileptics. Am J Psychiatry. 1961; 117: 832-833, doi: 10.1176/ajp.117.9.832, indexed in Pubmed: 13733416.

36. Ojemann LM, Baugh-Bookman C, Dudley DL. Effect of psychotropic medications on seizure control in patients with epilepsy. Neurology. 1987; 37(9): 1525-1527, doi: 10.1212/wnl.37.9.1525, indexed in Pubmed: 3627451.

37. Gross A, Devinsky 0, Westbrook LE, et al. Psychotropic medication use in patients with epilepsy: effect on seizure frequency. J Neuropsychiatry Clin Neurosci. 2000; 12(4): 458-464, doi: 10.1176/jnp.12.4.458, indexed in Pubmed: 11083162.

38. Divac N, Prostran M, Jakovcevski I, et al. Second-generation antipsychotics and extrapyramidal adverse effects. Biomed Res Int. 2014; 2014: 656370, doi: 10.1155/2014/656370, indexed in Pubmed: 24995318.

39. Casey DE. Side effect profiles of new antipsychotic agents. J Clin Psychiatry. 1996; 57 Suppl 11: 40-5; discussion 46, indexed in Pubmed: 8941170.

40. Diaz FJ, Eap CB, Ansermot N, et al. Can valproic acid be an inducer of clozapine metabolism? Pharmacopsychiatry. 2014; 47(3): 89-96, doi: 10.1055/s-0034-1371866, indexed in Pubmed: 24764199.

41. Spina E, D'Arrigo C, Santoro V, et al. Effect of valproate on olanzapine plasma concentrations in patients with bipolar or schizoaffective disorder. Ther Drug Monit. 2009; 31(6): 758-763, doi: 10.1097/ FTD.0b013e3181c0590e, indexed in Pubmed: 19865002.

42. Riedel M, Müller N, Strassnig M, et al. Quetiapine in the treatment of schizophrenia and related disorders. Neuropsychiatr Dis Treat. 2007; 3(2): 219 235, doi: 10.2147/nedt.2007.3.2.219, indexed in Pubmed: 19300555.

43. Syrek M, Wójcikowski J, Daniel W. Effect of carbamazepine on the pharmacokinetics of promazine. Pol J Pharmacol. 1996; 48(6): 601608, indexed in Pubmed: 9112700. 